\title{
NOTÍCIA SÔBRE A PARTE GERAL DO NÔVO CÓDIGO CIVIL PORTUGUËS *
}

\author{
J. LAMARTINE CORREA DE OLIVEIRA \\ (Docente-livre e Professor Adjunto de Direito Civil. \\ Professor de Direito Civil da Universidade \\ Católica do Paraná.)
}

\begin{abstract}
SUMÁRIO: INTRODUÇÃO: 1. Limitações e características do trabalho. Fontes consultadas. PRIMEIRA PARTE - ESCLARECIMENTOS E INFORMAÇÕES GERAIS - 2. O antigo Código português - antecedentes históricos, autoria, espírito inspirador, classificação de matérias. 3. O nôvo Código: a) sistema de preparação; b) espírito inspirador; c) classificação das matérias. SEGUNDA PARTE - A PARTE GERAL DO NÔVO CÓDIGO - 4. Pessoas singulares:

a) personalidade e capacidade de direito;

b) incapacidade de fato ou de exercício:

I - derivada da idade; a emancipação;

II - derivada de outras causas:

11.1: interdição e inabilitação.

11.2: técnica de enumeração das causas de interdição e inabilitação.

II. 3: O sistema do Código brasileiro.

II. 4: Comparação entre o sistema brasileiro e o português. A legislação brasileira extravagante.

II.5: O Direito pátrio, de lege ferenda, e o Projeto ORLANDO GOMES.

c) Ausência;

d) Domicílio;

e) Direitos da personalidade.
\end{abstract}

* Conferência pronunciada a 28 de janeiro de 1969, a convite do Instituto de Ciências Sociais e Direito Comparado da Universidade do Paraná. 
5. Pessoas coletivas:
a) Terminologia;
b) As sociedades na História do Direito, no Direito Brasileiro e no Direito Português.
c) O Código Português, as associações e fundações.

6. Coisas.
a) Modalidade da declaração;
b) Forma;
c) Perfeição do negócio jurídico;
d) Interpretação e integração do negócio jurídico;
e) Falta e vícios da vontade;
f) Representação;
g) Condição e têrmo;
h) Negócio jurídico nulo por ilicitude ou impossibilidade;
i) Lesão:
I. as três vertentes no Direito Comparado;
II. o Direito Brasileiro;
III. o Código Português.
¡) Insubsistência do negócio jurídico:
1. Inexistência e ineficácia;
II. Nulidade e anulabilidade: causas;
III. Nulidade e anulabilidade: conseqüências.
8. Prescrição e caducidade.

\section{N T R O D U Ç A O}

1. Limitações e características do trabalho. Fontes consultadas.

Notícia sôbre a Parte Geral do nôvo Código Civil Português. Necessàriamente, pouco mais que uma notícia. Pois que é extremamente vasta a matéria jurídica compreendida dentro da Parte Geral do Direito Civil e que, tendo êste trabalho nascido como texto para aula proferida em curso universitário, nasceu com as dimensões do tempo de uma aula. As ampliações que nêle introduzimos não poderiam alterá-lo substancialmente, sob pena de serem também extrapolados os limites de um artigo de revista. 
As circunstâncias em que nasceu êste trabalho - primeira aula de um curso, prelecionado por vários professôres, sôbre o nôvo diploma lusitano, explicam também a presença, no corpo do trabalho, desta Introdução e de uma Primeira Parte, destinada esta às explicações e informações genéricas sôbre o nôvo Código. Sendo nossa palestra a de abertura do curso, julgamos necessário, antes de entrar no tema Parte Geral, fornecer uma visão de conjunto, topográfica, doutrinária e histórica, do nôvo diploma. A preocupação didática de mostrar a amplidão da mudança introduzida pelo nôvo texto no Direito luso levou-nos à necessidade de compará-lo com o antigo Código, tornando necessário que umạ visão panorâmica do antigo diploma também se detivesse nos aspectos topográfico, doutrinário, histórico. É verdade que as minúcias a que tivemos de descer deram à Primeira Parte dêste nosso trabalho um caráter quase de mero repositório de informações. Se, apesar disso, essa coleta de dados tiver o mérito de divulgar conhecimentos nem sempre encontradiços entre nossos juristas e o de facilitar ao leitor eventual o conhecjmento de dados elementares sôbre o assunto, preparando a leitura da Segunda Parte, nosso objetivo terá sido alcançado.

Na Segunda Parte, encontra-se o núcleo essencial dêste trabaIho, o estudo daquilo que lhe dá o objeto - a Parte Geral do Nôvo Código Civil português. As mesmas limitações de espaço (na publicação) e tempo (no prelecionamento) já esclarecidas levaram-nos a optar - êste trabalho terá um caráter antes de informe e reflexão sôbre um nôvo texto legal que o de um ensaio em profundidade. Não tivemos, portanto, a preocupação de ampla referência bibliográfica, que seria essencial e imprescindível se fôssemos descer a um nível mais profundo de análise. Em tal nível, falar sôbre a Parte Geral de um Código Civil exigiria um curso, não uma aula; um livro, não um artigo.

Limitamos, quase que exclusivamente, nossas referências expressas a duas fontes fundamentais: a) no Direito Civil português, além do texto do próprio Código, os textos das publicações oficiais sóbre o Código - em especial, a Exposição de Motivos do Ministro ANTUNES VARELA e os textos dos vários anteprojetos parciais e trabalhos justificativos, publicados nessa admirável revista jurídica que é o Boletim do Ministério da Justiça de Portugal, tão pouco conhecido entre nós; b) no Direito não-português, os textos de. Direito Comparado, especialmente os textos dos Códigos que serviram de inspiração ao diploma luso. Especial preocupação tivemos em ter sempre presente a comparação com o Direito Brasileiro, vigente e projetado. 
Procuramos também ter sempre presente o texto do antigo Código Iusitano.

\section{PRIMEIRA PARTE - ESCLARECIMENTOS E INFORMAÇÕES GERAIS}

\section{O antigo Código português - antecedentes históricos, auto- ria, espírito inspirador, classificação de matérias.}

O nôvo Código civil português vem a público noventa e nove anos depois do velho Código. Com efeito, o antigo diploma foi aprovado por carta de lei de $1 .^{\circ}$ de julho de 1867 . O nôvo é aprovado por decreto-lei de 25 de novembro de 1966. Não chegou aos cem anos o velho diploma. $O$ antigo Código revogou a legislação que, tendo por base as Ordenações Filipinas de 1603 - embora estas houvessem sofrido reforma no reinado de D. MARIA I - fazia do Direito Civil Português um dos mais complexos pelo cipoal de velhas normas, fontes subsidiárias e leis extravagantes. Em 1867, Portugal ingressa na fase das grandes codificações da Era Contemporânea; o Brasil continuaria até 1917, paradoxal e anacrônicamente, sob o império básico das Ordenações seiscentistas, muito embora o cipoal entre nós tenha sido desbastado pelo paciente trabalho consolidador de TEIXEIRA DE FREITAS. O Código de 1867 é fruto do trabalho de um único jurista, ANTONIO LUIZ DE SEABRA, VISCONDE DE SEABRA. Como observa o Ministro ANTUNES VARELA, o velho diploma "é, com efeito, uma criação genuína do individualismo jurídico e da escola liberal, como logo o atestam o relêvo concedido aos chamados direitos originários, o caráter supletivo de quase tôda a regulamentação dos contratos, o culto prestado à regra da liberdade contratual e ao princípio da autonomia da vontade, o conceito da propriedade como projeção fiel da personalidade sôbre os bens do mundo exterior, e até a própria sistematização do diploma, cheia de originalidade, mas decalcada sôbre a biografia jurídica do cidadão isoladamente considerado". (') Com efeito: o velho Código dividia-se em quatro partes. A Parte I, dedicada à capacidade civil, regulava em seu Livro Único a nacionalidade e a capacidade das pessoas, aí incluída tôda a matéria relativa às chamadas pessos morais e, no que tange às pessoas naturais, os problemas da cidadania, do domicílio, da ausência, da incapacidade por menoridade, da filiação e do poder paternal, dos alimentos, da tutela, da curatela e das interdições. A Parte II destinava-se ao estudo "Da Aquisição dos direitos", subdividindo-se em três livros - I. dos direitos originários e dos que

(1) Portugal. Ministério da Justiça. A Reforma do direito civil. In ... "Projecto de código civil"..., pág. XIV. (Exposição de motivos do Ministro ANTUNES VARELA.) 
se adquirem por fato e vontade própria, independentemente da cooperação de outrem (abrangendo a ocupação, a posse, a prescrição - positiva e negativa -, o trabalho, aí incluído o trabalho literário e artístico e os direitos dos inventores); II - Dos direitos que se adquirem por fato e vontade própria e de outrem conjuntamente (abrangendo os contratos e obrigações em geral - capacidade, consentimento, objeto, conteúdo, interpretação, forma, rescisão, efeitos e cumprimento dos contratos; prestações, suas modalidades, formas de extinção das obrigações; garantia dos contratos - fiança, penhor, privilégios, hipotecas, registo; concurso de créditos; atos e contratos celebrados em prejuízo de terceiros, evicção; e, finalmente, os contratos em partícular, matéria que abrangia o casamento ao lado da sociedade, parceria, mandato, prestação de serviços, empreitadas, albergaria ou pousada, aprendizagem, depósito, doação, empréstimo, compra e venda, troca, locação, constituição de renda, usura, emprazamento (a nossa enfiteuse), transação); III - Dos direitos que se adquirem por mero fato de outrem, e dos que se adquirem por simples disposições de lei (abrangendo a gestão de negócios e a matéria sucessória). A Parte III dizia respeito ao direito de propriedade, abrangendo, ao lado da propriedade, o estudo das denominadas propriedades imperfeitas (quinhão, usufruto, uso, habitação, compáscuo e servidões), o estudo das acessões, do direito de transformação, das construções, plantações e restrições impostas à propriedade em defesa da propriedade alheia, dos muros e paredes meias; do direito de exclusão e defesa, restituição e indenização dos direitos violados, do direito de alienação. A Parłe IV - Da ofensa dos direiłos e sua reparação - compreendia a matéria relativa à responsabilidade civil, ao lado do Direito Material relativo às provas.

\section{O nôvo Código.}

Sob o tríplice critério aqui esboçado, distingue-se de modo radical o nôvo diploma do Código de SEABRA: pelo sistema de preparação, pelo espírito que o inspirou, pela classificação de matérias adotadas:

a) Sisłema de preparação. Não tem o nôvo Código um autor, mas vários. Em 1944, era Ministro da Justiça o ilustre civilista Professor ADRIANO VAZ SERRA. Sua Excelência tomou a iniciativa de ordenar a reforma do Código. Os trabalhos foram confiados aos mais variados especialistas, que se encarregaram de diferentes setôres do Código, redigindo ante-projetos e memoriais justificativos. Uma Comissão Revisora encarregar-se-ia de rever os ante-projetos, unificando-os, emendando-os, compatibilizando-os. O próprio nôvo Minis- 
tro da Justiça (ANTUNES VARELA, Ministro desde 1954, professor de Direito Civil) encarregar-se-ia pessoalmente de supervisionar os trabalhos de revisão e unificação. O Código é, portanto, obra em grande parte de ANTUNES VARELA. Mas é também fruto do traba!ho da Comissão. Dignos de menção especial são os autôres dos ante-projetos. No assunto de que nos ocuparemos neste primeiro trabalho, a Parte Geral, devem-se a MANUEL AUGUSTO DOMINGUES DE ANDRADE os Ante-projetos referentes ao comêço e têrmo da personalidade, direitos da personalidade, domicílio, fontes de Direito, vigência, interpretação e aplicação da lei, a FERRER CORREIA tôda a parte de conflitos de lei, incluído o Direito Internacional Privado, e também a parte relativa às pessoas jurídicas, que o Código chama de pessoas coletivas. Da autoria de MANUEL GONÇALVES PEREIRA, a parte referente à ausência. De PIRES DE LIMA, o subtítulo "Das Coisas" da Parte Geral, e um trabalho sôbre filiação, poder paternal, emancipação, tutela e maioridade que, embora não destinado ao Código, $\left({ }^{2}\right)$ deve ter servido de fonte de referência ao trabalho de DOMINGUES DE ANDRADE. De autoria de RUI DE ALARCÃO tôda a matéria referente ao Negócio Jurídico, exceção feita à parte relativa à perfeição da declaração de vontade que, juntamente com a matéria de prescrição e caducidade, e Direito probatório, é da lavra de ADRIANO VAZ SERRA. As incapacidades e forma de seu suprimento foram ante-projetadas por AMERICO DE CAMPOS COSTA.

b) Espírito inspirador. Pelo menos na intenção de seus autôres, a inspiração fundamental do nôvo diploma é anti-individualista, refletindo, nas palavras de ANTUNES VARELA, "em têrmos bastante equilibrados, a tendência social do Direito moderno, procurando conciliar pelos meios adequados o respeito que a lei deve à liberdade individual com as supremas exigências de uma ordem fundada na justiça e na reta convivência entre os homens, e harmonizando os benefícios da iniciativa privada com os deveres de solidariedade impostos pelo bem comum, pela paz social e pela segurança do direito". $\left(^{3}\right)$ O que pode ser resumido no dizer-se que o nôvo Código é típico de um Estado intervencionista, tendente à transformação da economia portuguesa em algo que se aproxime dos ideais do néo-capitalismo. Há, portanto, certa demasia em afirmar-se, embora de modo implícito, como faz o Ministro, estar o Código nôvo na linha da crescente socialização do Direito Privado. Ressalvada embora a

(2) in Boletim do Ministério da Justiça de Portugal, n. ${ }^{\circ} 89$, págs. 23/123. Doravante citaremos tal publicação como BMJ, seguindo-se imediatamente o número da publicação e, depois, o das páginas.

(3) Exposição de motivos, pág. XXXI. Ver a nota (1) retro. 
ambigüidade da palavra socialização, ressalva que o próprio Ministro se apressa a fazer, não nos parece que se possa aplicar tal têrmo às reformas que o Código introduz, na ordem econômica e social. No domínio que nos vai interessar neste primeiro trabalho - a Parte Geral e seguindo ainda o critério do próprio Ministro ANTUNES VARELA, os dispositivos inovadores seriam, principalmente, os relativos ao princípio da boa fé em matéria de interpretação, integração e formação do negócio jurídico, e em matéria de negócio jurídico condicional; a consagração do êrro sôbre a base do negócio (Geschäftsgrundlage), a condenação dos negócios usurários, e a forma adotada para a consagração do velho instituto da lesão. $\left(^{4}\right)$ Ressalte-se que é manifestamente pouco para que se possa falar em socialização...

Por outro lado, ainda para aproveitarmos a brilhante exposição de ANTUNES VARELA, o Projeto, transformado em Código, quis representar um reconhecimento do fracasso do positivismo jurídico e da superstição da onipotência da lei, aceitando, por isso, a existência de realidades praeter legem, a influir diretamente sôbre a lei - v. g., as convicções religiosas ou as cogitações morais. Os exemp'os mais frisantes de tal traço no nôvo diploma - a solução dada ao problema das obrigações naturais, e a regulação das doações usuais; a eficácia civil do casamento católico, e o reconhecimento das lacunas da lei $\left({ }^{5}\right)$ - situam-se todos fora do âmbito da Parte Geral. Necessária limitação de método obriga-nos a desprezar a análise de tão sedutora matéria. A mesma razão nos obriga a deixar de lado as considerações sociológicas que, a propósito das relações familiares, podem ser inspiradas pelo Código.

c) Classificação das matérias. Foi abandonada a original mas superada e pouco científica classificação de SEABRA (supra, item 2). Como na maioria dos Códigos dêste século, é a classificação alemã a adotada. A matéria do Direito Civil classifica-se em Parte Geral, e em quatro partes especiais - Obrigaçõese, Coisas, Família, Sucessões, nessa ordem, diversa da adotada pelo nosso Código, idêntica à ordem com que a matéria é lecionada hoje na nossa e na maioria das Faculdades brasileiras, e à ordem de disposição dos mais respeitados diplomas - do BGB de 1896 ao relativamente recente

(4) Idem, pags. XXIII - XXIV.

(5) Quanto a êste ponto, queremos apenas chamar a atenção para o texto do art. 10, al. 3 do Código em estudo, onde, após regulada a integração das lacunas da lei pelo recurso à analogia, é determinado: "Na falta de caso análogo, a situação é resolvida segundo a norma que o próprio intérprete criaria, se houvesse de legislar dentro do espírito do sistema". Seria interessante um estudo comparativo entre as noções de espírito do sistema e de princípios gerais do Direito. 
Código helênico de 1941. Desprezou-se por conseguinte a sistemática francesa, a antiga sistemática do velho Código luso, a novíssima taxinomia italiana. Posta de lado também a idéia de unificação do Direito Privado, quer totalmente - sistema italiano - quer quanto ao Direito das Obrigações - sistema suíço e o dos projetos brasileiros CAIO MÁRIO-ORLANDO GOMES, hoje postos de lado. Ao lado do Código Civil, terá Portugal ainda o Comercial.

Quanto à PARTE GERAL, de que nos ocuparemos a seguir, foi a seguinte a sistemática adotada. Dois títulos, destinado o primeiro à matéria que PONTES DE MIRANDA denomina super-direito, e que entre nós constitui o objeto da Lei de Introdução - as fontes do Direito, a vigência, interpretação e aplicação das leis, e a matéria de Direito Internacional Privado. Tudo isso é estranho ao nosso assunto que pertine tão só à matéria estritamente de Direito Civil. Desta se ocupa a Parte Geral em seu Título II - Das relações jurídicas. Só dêste Título II é que nos ocuparemos. A matéria está subdividida em quatro subtítulos. Dos quais o último, que regula o exercício e a tute!a dos direitos, será estudado por outro expositor. Ocupar-nos-emos dos três subtítulos primeiros do Título II da Parte Geral. O quarto sub-título, a cargo de outro expositor, contém o chamado Direito Probatório Material, guarda íntimas relações com o Direito Judiciário. Os três primeiros, que nos vão interessar, envolvem disposição da matéria que, vinda do Código alemão, é extremamente semelhante à brasileira. No primeiro, as pessoas. Inicialmente, as pessoas singulares (expressão que corresponde a pessoas "naturais" no nosso Código). Sua personalidade e capacidade. Os direitos de personalidade. $O$ domicílio. O instituto da ausência que, com melhor técnica que a do nosso Código, não é encarada como causa de incapacidade. As incapacidades vêm a seguir - a condição jurídica dos menores, o término da menoridade; as outras causas de incapacidade, geradoras de interdições ou de inabilitações. Depois, as pessoas jurídicas, que o Código chama de pessoas coletivas. Ao lado delas, a regulação de determinados grupamentos não-personificados. No segundo sub-título, as coisas, conceitos e subdivisões. No terceiro, os fatos jurídicos, em sentido amplo. Êste subtítulo está dominado pela disciplina geral do Negócio Jurídico, que segue o esquema do item 7 de nosso trabalho, letras a até j. Um segundo capítulo faz breve referência aos ałos jurídicos não-negociais, aplicando-lhes as normas relativas aos negócios jurídicos. O subtítulo encerra-se com o estudo do tempo e suas repercussões nas relações jurídicas, onde é particularmente importante a disciplina da prescrição e da caducidade. 


\section{SEGUNDA PARTE - A PARTE GERAL DO NÔVO Código.}

\section{Pessoas singulares: a) personalidade e capacidade de direiło.}

O comêço da personalidade é determinado - art. 66 - pelo nascimento com vida. Melhorou-se consideràvelmente a fórmula do antigo Código que, em seu art. 6, dizia adquirir-se a "capacidade jurídica pelo nascimento". Por um lado, como mostraremos logo em seguida, não se confunde mais personalidade com capacidade jurídica; por outro, deixa-se claro agora que é o nascimento com vida, o nascimento cujo fim tenha sido inteiramente atingido - vollendet, para usar a extremamente expressiva fórmula do § 1 do diploma germânico, que é suporte fáctico da aquisição da personalidade. Sente-se a nítida influência do Código brasileiro, art. 4. À 2. ${ }^{a}$ parte dêste dispositivo - "mas a lei põe a salvo desde a concepção....." corresponde a al. 2 do art. 66 português - "os direitos que a lei reconhece aos nascituros dependem do seu nascimento". É a consagração do princípio nasciturus pro jam nato habetur...

Pessoalmente, embora reconhecendo que o Código Português melhorou a redação do princípio, se comparamos seu art. 66, al. 2, com o art. 4, 2. a parte, do diploma brasileiro, confessamos nossa preferência pe'a fórmula, que era a de TEIXEIRA DE FREITAS, e que o Código argentino consagrou: a personalidade começa com a concepção, embora o não-nascimento com vida tenha fôrça de condição resolutiva dos direitos já adquiridos, ou, dita a coisa por outra forma, o nascimento com vida funcione como condição suspensiva do caráter definitivo dessa aquisição de direitos. É a fórmula do art. 70 do diploma argentino, no qual o nascituro, pessoa e capaz de direitos, é absolutamente incapaz de exercício dos mesmos direitos, cfr. art. 54, $1^{\circ}$. Tal fórmula evita a contradictio in terminis que consiste em reconhecer direitos a quem, supostamente, é ontológica e juridicamente incapaz de ser titular de direitos, por não ser ainda pessoa.

Assim como no Direito Brasileiro, a personalidade cessa com a morte (Cód. Port. art. 68, 1; Bras., art. 10, 1. ${ }^{a}$ parte) estabelecendo-se presunção juris taníum de morte simultânea "quando certo efeito jurídico depender da sobrevivência de uma a outra pessoa" (art. 68, 2) e permitindo-se prova indireta de morte no art. 68, 3 para o caso de "pessoa cujo cadáver não foi encontrado ou reconhecido, quando o desaparecimento se tiver dado em circunstâncias que não permitam duvidar da morte dela". Em forma tècnicamente menos bem elaborada, o Direito Brasileiro permite essa forma de 
prova indireta de morte no art. 99 da Lei dos Registros Públicos. (Atualmente, art. 85 do Decr. lei 1.000, de 21 de outubro de 1969.)

Extremamente importante é $\circ$ art. 67 do nôvo diploma luso. "As pessoas podem ser sujeitos de quaisquer relações jurídicas, salvo disposição legal em contrário: nisto consiste a sua capacidade jurídica". Em tal dispositivo, sob a rubrica de capacidade jurídica, estabelece-se nítida distinção entre a personalidade e a capacidade de direito ou de gôzo. A primeira é suporte fáctico da segunda, pois não é possível admitir-se que quem não seja pessoa seja titular de direitos. Porém as duas expressões não guardam entre si identidade. A personalidade é quantidade invariável, insuscetível de gradações. Não é possível ter-se meia personalidade, personalidade incompleta, personalidade restringida - ou se é pessoa ou não se o é. Ao contrário, a capacidade de direito admite gradações, restrições, limitações. O Direito Brasileiro, embora ofereça exemplos práticos de tais limitações - veja-se, v.g... a situação dos estrangeiros, impedidos, por lei, de adquirirem, de serem titulares (não se trata de uma simples incapacidade de exercício) de determinados direitos subjetivos, públicos ou privados, não conhece, no Código Civil, a consagração da necessária distinção conceitual. Tal distinção, que é uma das conquistas da moderna doutrina civilísta $\left({ }^{6}\right)$, encontra ampla consagração na fórmula extremamente feliz do art. 67 do diploma lusitano, ao ressalvar $\circ$ artigo as disposições legais em contrário que podem limitar a capacidade jurídica - não a personalidade das pessoas. Antes dessa disposição portuguesa, o melhor antecedente que conhecemos, embora tècnicamente inferior, é o art. 11 do Código Civil Suíço - "Toute personne jouit des droits civils. - En conséquence, chacun a, dans les limites de la loi, une aptitude égale à dévenir sujet de droits et d'obligations".

\section{b) Incapacidade de fato ou de exercício.}

Nessa matéria, é totalmente distinto do nosso o sistema do nôvo diploma português. Não se dividem as incapacidades em absolutas e relativas, como fazem o nosso diploma e o argentino, e como continua a fazer o Projeto ORLANDO GOMES de Código Civil.

(6) Näo obstante, a Doutrina Brasileira, em sua generalidade, não parece ter-se apercebido de tal conquista. A mais ilustre exceção é a de PONTES DE MIRANDA, que distingue nìtidamente os dois conceitos ("Tratado de Direito Privado", tomo 1, Borsoi, Rio 1954, págs. 159, 161, 280, 282, 284). Tivemos ocasião de desenvolver longamente o tema em tese de concurso ("Conceito da pessoa jurídica", Curitiba, 1962, págs. 76 e 99) e em artigo de revista ("Personalidade jurídica da sociedade irregular", in "Revista da Faculdade de Direito da Univ. Federal do Paraná", ano 10, n.0 10, págs. 139-161 e em "Revista Jurídica", de P. Alegre, RS, vol. 76, págs. 5-26, ano 1967). 
É tão diverso o sistema português que será necessária uma descrição um pouco mais minuciosa.

Há duas causas possíveis de incapacidades - as que derivam da idade, e que independem de qualquer ato judicial, e as derivadas de outras causas, e que só surgem no mundo jurídico através de ałos judiciais, constitutivos, de interdição ou de inabilitação.

\section{i - Incapacidade derivada da idade; a emancipação.}

A maioridade atinge-se aos vinte e um anos de idade. Antes de tal idade, as pessoas de um e outro sexo são menores e, "salvo disposição em contrário, carecem de capacidade para o exercício de direitos" - arts. 130, 122 e 123 do nôvo Código. A fonte é, em grande parte, o velho Código luso, em seus arts. 97 e 98. Tal incapacidade é suprida pelo poder paternal e, subsidiàriamente, pela tutela (art. 124; fonte - art. 100 do velho Código). Não existindo, porém, gradações de idade para fins de estabelecimento de diversificação nos tipos de incapacidade, como sucede no Direito Brasileiro, - menor é sempre representado, jamais assistido, pelo titular do poder paternal ou pelo tutor. (arts. 1885 e 1935, 1) Essa incapacidade do menor, embora não sujeita a graus, não é total. Há determinadas exceções à incapacidade do menor, previstas no art. 127. Se o menor, por seu trabalho ou indústria, exercido com permissão dos pais, ou pelas armas, letras ou profissão liberal, adquire bens, dos mesmos pode dispôr, e os mesmos pode administrar, por si mesmo. Como é capaz para a prática dos negócios jurídicos relativos à profissão, arte ou ofício que tenha sido autorizado a exercer. De onde se depreende a existência de um instituto semelhante - embora mais amplo - à autorização para comerciar do nosso Código Comercial. Por outro lado, é o menor capaz para a prática dos negócios jurídicos que, "estando ao alcance da sua capacidade natural, só impliquem despesas, ou disposições de bens, de pequena imporrância. Não nos parece tal dispositivo (art. 127, 1, b) dos mais felizes, pois a noção de "capacidade natural" introduz o arbítrio judicial, ao qual é também feito apêlo para a determinação do limite entre pequena e grande importância das despesas ou disposições de bens. Embora o sistema brasileiro seja mais rígido - e é previsível o argumento segundo o qual a múltipla variedade das pessoas não permite sem artificialismo o enquadramento em uniforme esquema legal é preferível, do ponto de vista da segurança jurídica. O Código Português não distinguiu entre menores absoluta e relativamente incapazes. Todos são incapazes, e representados por quem de direito. Não tendo querido admitir a gradação de capacidade, marcada teórica 
e tradicionalmente pela puberdade (a exemplo, aliás, de inúmeros códigos europeus, que também não consagram a distinção entre o menor púbere e o impúbere - francês, art. 488; Alemão, § 2; Suíço, arts. 14 e 17), o Código português, premido pela realidade da vida, acabou tendo de abrir exceções à incapacidade e permitir o arbítrio judicial. Resta observar que, no sistema luso, sendo os menores incapazes, os atos que praticarem por si, sem seus representantes legais, são sempre anuláveis, não importando a idade do menor, inexistindo nulidade absoluta com tal fundamento.

Desaparece a incapacidade derivada da idade ou pelo advento da maioridade ou pela emancipação. Ressalvada a hipótese de emancipação por fôrça do casamento, a emancipação é possível após completados dezoito anos de idade. (arts. 129, 132, 134, 135) Não há maiores diferenças relativamente ao sistema brasileiro. Ao contrário, porém, do nosso Direito, o tutor não tem a menor ingerência em matéria de emancipação. Na matéria, tem importância, ao contrário, "na falta dos pais ou estando êles inibidos do poder paternal" (art. 132, c) ○ "conselho de família", curiosa instituição de origem francesa, presidida pela autoridade judiciária, mas integrada pelos parentes do menor, e que o Código mantém, para essa e outras finalidades, e cuja importância vai aparecer em matéria de tutela. Essa instituição foi denominada por PIRES DE LIMA "pequeno parlamento dentro do pequeno Estado que é a família", dela afirmando - ilustre jurista luso que "tem sobejamente revelado a sua inutilidade", tratando-se, segundo êle, de "velharia que nos legou o Código napoleônico e que aceitamos com quebra da nossa tradição jurídica". (7) Não obstante tão veemente crítica, a instituição foi mantida. Acrescente-se que a criação da capacidade restrita para exercício de profissão dispensou o Código português de criar emancipação por estabelecimento com economia própria, como fêz o nosso, em solução abolida pelo Projeto ORLANDO GOMES. Resta mencionar que, em dois pontos importantíssimos, o Código português difere do nossos sistema - ao criar uma espécie de emancipação restrita a determinados atos ou categorias de atos - art. 136 e ao atribuir à emancipação natureza de ato revogável por decisão do Tribunal de Menores, podendo a decisão revocatória inclusive ser proferida ex-officio - art. 137. Quanto ao primeiro ponto, frise-se desde logo tratar-se da única concessão feita pelo Código português à tendência de alguns diplomas modernos a distinguirem entre emancipado e maior. Além de tal dispositivo, há apenas o art. 133, que atribui ao menor emancipado plena capacidade de exercício dos

(7) BMJ, n.0 89, pág. 33. 
direitos, ressalvando apenas o já mencionado art. 136 e o art. 1.649 que, no caso de emancipação por fôrça de casamento não autorizado, nega capacidade ao emancipado quanto à administração dos bens que leve para o casal ou que posteriormente the advenham por título gratuito. Êste último dispositivo é evidentemente uma disposição protetiva de patrimônio familiar, semelhante, embora com técnica diversa, à separação legal de bens prevista pelo nosso art. 258, parágrafo único, I, combinado com o art. 183, XI. Nossa solução parece superior: cria-se regime legal de separação, mas não se introduz pai nem tutor na administração de bens de pessoa casada. A solução portuguesa, embora mais rigorosa como medida de proteção, cria visível incoerência com o estado de emancipado. Dado seu caráter excepcional, explica-se o havermos dito ser essa a única restrição aos direitos do emancipado: a hipótese da denominada emancipação restrita, que já é assim, restrita, ab initio. De qualquer modo, fugiu-se da infeliz solução italiana, a qual prevê, como regra geral, a subordinação do emancipado a um regime de curatela Cód. It., art. 392 - só atribuindo ao emancipado uma capacidade restrita aos atos de administração ordinária - Cód. It., art. 394. Quanto ao caráter revogável que o nôvo diploma português atribuí à emancipação, rompendo com o disposto pelo antigo Código português, art. 310, a fonte parece ter sido a disposição do art. 398 do Código de 1942 (rubrica "Revoca dell'emancipazione") em que, como no Código português, é atribuído amplo arbítrio à autoridade judiciária para julgar da conveniência da mantença ou revogação da emancipação. No Código Italiano, porém, em que a emancipação não confere capacidade plena, mas apenas limitada aos atos de administração, a revogação guarda uma certa linha de coerência. Totalmente inconveniente e perigosa, porém, é a revogabilidade em regime como o português, em que a regra geral da emancipação é a p'ena equiparação ao maior. O mesmo defeito do Código luso, pode ser, aliás, encontrado no Projeto ORLANDO GOMES, art. 11, § 2.․

\section{Incapacidades derivadas de outras causas.}

As demais incapacidades de fato dependem sempre de decisão judicial, que constitui sempre o estado de incapacidade ou, como preferiria PONTES DE MIRANDA, desconstitui a capacidade.

\section{1: Interdição e inabilitação.}

No sistema criado pelo Código português, por proposta do Ante-projeto CAMPOS COSTA, há duas espécies de decisões judiciais no terreno que agora estudamos - as interdições e as inabilitações. 
São causas de interdição: anomalia psíquica, surdez-mudez e cegueira. A enumeração é taxativa. Mas, em qualquer dos três casos, só cabe a interdição quando, a critério judicial, uma das causas tenha gerado efeito que é parte integrante do suporte fáctico - os interditandos "se mostrem incapazes de governar suas pessoas e bens" - art. 138. São causas de inabilitação - art. 152 -: a) a anomalia psíquica, a surdez-mudez ou a cegueira, quando tais defeitos, "embora de caráter permanente, não seja $(m)$ de tal modo grave que justifique $(m)^{\prime \prime}$ a interdição; b) a habitual prodigalidade, ou o abuso de bebidas alcoólicas ou de estupefacientes quando, a critério judicial, qualquer destas causas tenha gerado efeito que é parte integrante do suporte fáctico - os inabilitandos "se mostrem incapazes de reger convenientemente o seu patrimônio". Se o caso é de prodigalidade habitual ou abuso de bebidas alcoólicas ou estupefacientes, há duas hipóteses - ou tais causas tornaram o indivíduo incapaz de reger convenientemente seu patrimônio (e nessa hipótese cabe inabiliłação) ou não produziram tal efeito (e então não cabe nem interdição nem inabilitação). Se, porém, o caso é de anomalia psíquica, surdez-mudez ou cegueira, é necessário, para que haja interdição, que os indivíduos "se mostrem incapazes de governar suas pessoas e bens"; poderá haver inabilitação quando o defeito, embora permanente, "não seja de tal modo grave que justifique a interdição". O critério de opção entre interdição e inabilitação nos casos de anomalia psíquica, surdez-mudez ou cegueira é então meramente quantitativo, confessa-o AMÉRICO CAMPOS COSTA, autor do Ante-Projeto. $\left({ }^{8}\right) \bigcirc$ interditado é subordinado a um tutor, que o representa nos atos da vida civil, sendo equiparado a um menor, pois as normas da tutela dos menores aplicam-se subsidiàriamente aos interditados - art. 139. O inabilitado é assistido por um curador. À autorização dêste estão sujeitas duas espécies de atos: a) os de disposição de bens entre vivos; b) os que, em atenção às circunsfâncias de cada caso, forem especificados na sentença. Há, por conseguinte, inabilitações maiores ou menores, conforme a sentença, sendo portanto a inabilitação quantidade variável, ao contrário da inferdição. Com isso, a Comissão Revisora contrariou o Ante-Projeto CAMPOS COSTA, que previa a invariabilidade, quer da interdição, quer da inabilitação. Mostrou mais uma vez o Código sua tendência a soluções elásticas, confiada a decisão ao prudente arbítrio judicial. Os atos praticados, sem a representação do tutor (interditos) ou sem a assistência do curador, nos casos em que esta se faça necessária (inabilitados) são anuláveis - a) quando celebrados depois do re-

(8) BMj n.o 111, pág. 224 
gistro da sentença de interdição ou inabilitação; b) quando, celebrados pelo incapaz depois de anunciada a proposição da ação nos têrmos da lei processual, a interdição ou inabilitação venha a ser decretada e se mostre que o negócio causou prejuízo ao interdito ou inabilitado (arts. 148, 149, 1 e 156). Aos negócios celebrados pelo incapaz antes de anunciada a propositura da ação, manda o art. 150 aplicar o dispôsto acêrca da incapacidade acidental. Trata-se de instituto que já existia no antigo Código - art. 353 - e que o atual manteve, no seu art. 257, que permite a anulação de ato praticado por indivíduo capaz que "se encontrasse acidentalmente incapacitado de entender o sentido" da declaração ou não tivesse o livre exercício da sua vontade, contanto que o fato fôsse notório ou conhecido do declaratário, entendendo-se por fato notório o que uma "pessoa de normal diligência (o) teria podido notar". Assim, embora as incapacidades por doenças mentais ou físicas, por embriaguez, abuso de tóxicos ou prodigalidade, só se instaurem por decisão judicial, que não as declara, mas as cria, e que só é possível em caso de caráter habitual de tais anomalias, o Código abre uma exceção no caso das incapacidades acidentais, conhecidas ou notórias. Assim, o indivíduo, mesmo que ébrio contumaz, não é incapaz, se não está inabilitado. Mas se é evidente e fàcilmente perceptível o estado de embriaguez em que se encontra no momento do ało jurídico, tal ato é anulável por incapacidade acidental.

\section{2: Técnica de enumeração das causas de interdição e ina- biliłação.}

A técnica de enumeração taxativa das doenças físicas capazes de integrar o suporte fáctico da interdição ou da inabilitação é diversa da dos precedentes legislativos. O Código alemão fala em doenças físicas, ou melhor, invalidez física - körperliche Gebrechen - especialmente quando o portador seja surdo, cego ou mudo - insbesondere weil er taub, blind oder stumm ist $-\S 1.910$, o que deixa denotar o caráter exemplificativo da enumeração de surdez, cegueira ou mudez. O Código grego, que citamos na tradução francesa oficial, na esteira do diploma germânico, menciona, no art. 1.686, 2. "ce'vi qui, à cause d'une infirmité corporelle, et notamment du fait qu'il est sourd, aveugle ou muet de naissance..." Não é nôvo, porém, - sistema, globalmente considerado. Os dois mais ilustres antecedentes, referidos aliás pelo próprio CAMPOS COSTA, são os Códigos helênico e italiano. O primeiro prevê a tutela e a interdição para as pessoas portadoras das enfermidades corporais, especialmente as mencionadas no art. $1.686,2 .^{\circ}$, que vem de ser citado, e para os portadores de doença mental durável e que se encontrem hors d'état 
de prendre soin de sa personne ou de son patrimoine - art. 1.686: Ressalte-se a semelhança de fórmula. Prevê ao mesmo tempo um conseil judiciaire para as pessoas cuja doença mental não exclua inteiramente o uso da razão, ou de estado mental duvidoso, ou cuja enfermidade corporal não acarrete a impossibilidade completa de prendre soin de sa personne et de ses affaires - art. 1.691 - além dos pródigos, ébrios e toxicômanos - art. 1.705. Quanto aos pourvus de conseil judiciaire, submetidos a tal conselho por sua enfermidade menos grave, o necessário assentimento do conselho judiciário é limitado aos atos que o Código enumera no art. 1.707. O Código Italiano prevê a interdição daqueles que si trovano in condizioni di abituale infermità di mente che li rende incapaci di provvedere ai propri interessi - art. 414 - e a inabilitação dos doentes mentais, quando seu estado non è talmente grave da far luogo all'interdizione, bem como dos que per prodigalità 0 per abuso abiłuale di bevande alcooliche o di stupefacenti, espongono sè o la loro famiglia a gravi pregiudizi economici, e finalmente, a dos surdo-mudos e cegos de nascença ou que assim se tenham tornado na primeira infância, e que não tenham recebido educação suficiente - art. 415. Aos surdo-mudos e aos cegos, conforme o caso, pode porém aplicar-se a interdição. Ainda no sistema italiano, os interditados são subordinados a um tutor, aplicando-se-lhes as normas relativas aos menores sob tutela, e os inabilitados são subordinados a um curador sendo-lhes aplicáveis as normas relativas aos menores emancipados.

\section{3: O sistema do Código brasileiro.}

Sabe-se que é totalmente diverso. De acôrdo com a doutrina entre nós dominante, no sistema do Código, a interdição tem natureza constitutiva da incapacidade quando a causa da interdição é daquelas que geram incapacidade relativa - é o caso da prodigalidade. Tem, porém, natureza declaratória de incapacidade pré-existente no caso das incapacidades absolutas. A interdição produzirá efeitos ex func no caso do louco e seus atos serão nulos desde que se prove tenham sido praticados em estado de loucura, estivesse ou não interditado e mesmo que jamais a interdição o tenha atingido. Por outro lado, entre nós, é sempre sob curatela que ficam os interditos, já que a tutela é instituto só aplicável aos menores, como sucedâneo do pátrio poder. Entre nós, o curador é representante quanto aos absolutamente incapazes, assistente quanto aos relativamente, e a invalidade é do tipo das nulidades no caso das incapacidades absolutas, do tipo das anulabilidades no caso das incapacidades relativas. Só no caso da interdição dos surdo-mudos, admite 
nosso Código certo arbítrio do juiz - art. 451 - no assinalar os limites da curatela. Não há, porém, incapacidade relativa de surdo-mudo, embora interditado. O surdo-mudo ou é capaz, ou absolutamente incapaz, ou capaz quanto a certos atos, absolutamente incapaz quanto a outros. Não há, entre nós, anulabilidade de ato jurídico por surdo-mudez de um de seus partícipes. Ou os atos do surdo-mudo são nulos, ou válidos. O cego não é previsto no nosso elenco de incapazes.

\section{4: Comparação entre o sistema brasileiro e o português. A legislação brasileira extravagante.}

O sistema do nosso Código é, assim, de geométrica clareza e rigidez. Mesmo no caso dos pródigos, o Código claramente prevê os atos que êle não pode praticar sem a assistência do curador art. 459. Só no caso do surdo-mudo é que, como vimos, é permitida ao julgador certa margem de arbítrio. Ainda porém que tal margem seja levada em conta, a margem aberta ao arbítrio judicial pelo Código luso é muito maior. Nos casos de interdição, pode a medida ser substituída pela inabilitação. E nos casos em que cabe esta, ou que só cabe esta, os limites da incapacidade gerada pela inabilitação podem ser ampliados ou estendidos, a critério do juiz. Apesar da crítica velada feita por CAMPOS COSTA ao Código venezuelano $\left(^{8}\right)$ por admitir êste que a inabilitação abranja até os atos de simples administração, quando tal medida se mostre necessária, o Código luso terminou por adotar a medida variável de incapacidade em decorrência da inabilitação: o inabilitado depende do curador para os atos de disposição de atos entre vivos; dêle dependerá também para todos os outros atos que a sentença judicial julgar conveniente incluir na especificação da extensão de sua incapacidade - art. 153. É verdade que essa variabilidade de medida da inabilitação contraria as idéias do Ante-projeto original.

Há, portanto, da parte do Código português, ainda uma vez, a opção pela elasticidade e pela concessão de largo arbítrio ao poder judiciário. Como houve, da parte de nosso Código, a opção pela clareza cartesiana de um equacionamento rìgidamente correspondente a definidas figuras geométricas. Mesmo entre nós, porém, a legislação extravagante viria esbater essa clareza de linhas. O Decreto 24.559 e o Decreto-lei 891 admitiram pudesse o juiz, no despacho de nomeação de um administrador provisório de bens, ou na sentença de interdição, definir a incapacidade do doente mental como abso-

(8) BMJ n.० 111, pág. 224. 
luta ou relativa, o que criou uma figura nova em nosso Direito - a do doente mental relativamente incapaz. Não nos parece, que o Judiciário tenha dispensado boa acolhida prática, na vida do Forum, à nova categoria. Essa legislação posterior ao Código previu também a interdição dos toxicômanos, em dispositivos à parte, implìcitamente não os considerando como loucos de todo o gênero.

O que se deve daí inferir é que nosso Código se encontra desatualizado, ao pretender abranger na ampla fórmula - loucos de todo o gênero - casos que os progressos da moderna psiquiatria dificilmente permitiriam reduzir a uma fórmula única, a uma única categoria. É evidente, porém, como quase sempre acontece, que a legislação extravagante não primou pelo amor ao sistema e acabou por criar novas e mais graves perplexidades para $\circ$ exegeta e $\circ$ aplicador da lei.

\section{5: O Direito pátrio, DE LEGE FERENDA, e o Projeto ORLAN- DO GOMES.}

O professor ORLANDO GOMES, ocupando-se do assunto a respeito de seu Projeto, teve oportunidade de analisar a solução italiana, idêntica na essência, como vimos, à portuguesa. Fazemos nossas as seguintes palavras do civilista bahiano - "Manifesta-se seu defeito maior na subordinação ao arbítrio do juiz do grau de incapacidade. Absolutamente incapaz não é o insano mental, senão quem o juiz interdita por essa razão, o que permite, dada a variedade de critério, seja apenas inabilitado o portador da mesma moléstia mental, por outro juiz interdito." (9) Aceitamos a crítica de ORLANDO GOMES, ressalva feita da transposição que, inadvertidamente, no texto, o mestre efetuou, da categoria de incapacidade absoluta para sistema que, como tal, a desconhece. Endossamos também a previsão feita por ORLANDO GOMES no sentido de que, se tal sistema fôsse adotado no Brasil, só conheceria nosso Forum casos de inabilitação, jamais de interdição. Não cremos, porém, que o Projeto ORLANDO GOMES, concessa venia, haja encontrado correta solução para o problema. A emenda parece estar, nos pontos em que inova, pior que o soneto. Permite-se no Projeto que, na sentença de interdição, fixe o juiz os limites da curatela. Embora afirme ORLANDO GOMES que, no caso, teríamos uma incapacidade não-absoluta, teríamos, na realidade, pois que o curador continuaria representante, uma incapacidade absoluta parcial, o que, dado o efeito meramente declaratório da interdição, poderia colocar loucos interditados em situação de maior capacidade que a de loucos não-interditados. O

(9) ORLANDO GOMES, "A Reforma do Código Civil", Bahia, 1965, pág. 109. 
disposto no art. 315, do Projeto ORLANDO GOMES - "Se a perturbação mental não excluir inteiramente o uso da razão, o juiz poderá nomear administrador, em vez de decretar a interdição" - é a inabiliłação sem o nome, e com outras desvantagens. Com efeito, em tal fórmula não se sabe se são válidos, nulos ou anuláveis os atos praticados pelo doente submetido à administração sem a ingerência do administrador. O fato de prever o Projeto ORLANDO GOMES uma fórmula ampla - "os que, por enfermidade mental, não tiverem discernimento para a prática dos atos da vida civil" art. 6. ${ }^{\circ}, 11,1.9^{a}$ parte - agrava o pecado do sistema projetado, ampliando o arbítrio do juiz que, ao menos, é um pouco limitado pela técnica italiana e lusa de enumeração taxativa dos casos que autorizam interdição ou inabilitação. Ainda cremos que a melhor técnica, de lege ferenda, encontra-se, no rígido sistema de nosso Código, aperfeiçoado talvez por uma dicotomia, tanto quanto possível haurida na terminologia psiquiátrica, entre dois tipos de incapacidade por perturbação, debilidade ou doença mental. Esperamos que os membros da Comissão encarregada da reforma do Código Civil Brasileiro atentem para êsses aspectos do problema.

Acrescente-se ainda que, no Projeto ORLANDO GOMES, o pródigo não é incluído entre os incapazes, mas continua sujeito à interdição, o que não altera muito a atual situação, do ponto de vista prático, dado o caráter constitutivo de incapacidade que tem a interdição do pródigo.

\section{c) Ausência.}

A AUSÊNCIA não é encarada pelo Código português como causa de incapacidade, o que nos parece tècnicamente mais correto que a disposição de nosso Código - art. $5 .^{\circ}$, IV - que consagra a incapacidade do ausente. Incapacidade, aliás, que não corresponde ao rigor técnico da expressão. Tanto assim que os atos que eventualmente o ausente pratique no local onde se encontre não são nem nulos nem anuláveis, mas plenamente válidos. Dados os limites dêste trabalho, e a necessidade de optar entre pontos que serão mais desenvolvidos e pontos que serão abordados de modo mais superficial, pouco diremos quanto à ausência. Até pela razão de que, na sistemática brasileira, a matéria integra o Direito de Família, embora a inclusão na Parte Geral (sistema luso) nos pareça mais correta. Fiel à corrente latina em matéria de ausência, o Código português prevê três fases - 1) a da curadoria provisória, correspondente à nossa fase de curadoria de ausentes (Cód. Port., arts. 89-98; Bras. 463-468) - trata-se de fase que é mais minuciosamente regulada em Portugal e Brasil 
que na maioria dos países; 2) a da curadoria definitiva, correspondente à nossa fase de sucessão provisória (Port.: 99-113: Bras.: 469-480) - é fase que é aberta pela justificação judicial de ausência, sendo que GONÇALVES PEREIRA, autor do Ante-projeto português, critica a terminologia brasileira - "sucessão provisória" - como imprópria, por implicar tomada de posição em favor de um caráter sucessório do processo relativo aos bens do ausente $\left({ }^{10}\right)$; 3 ) a da morte presumida, correspondente à nossa fase da sucessão defintiva. (Port.: 114-121; Bras.: 481-484) Nessa última fase, cria o Código Português verdadeira e total presunção de morte, não conhecendo a limitação prevista pelo nosso art. 315, parágrafo único, que veda o nôvo casamento do cônjuge do ausente. O Código Português, ao contrário, permite êsse nôvo casamento, caso o anterior casamento do ausente seja civil: se o ausente reaparecer ou houver notícia de que era vivo, quando foram celebradas as novas núpcias, considera-se o anterior casamento dissolvido pelo divórcio (art. 116, 1). No caso de ser católico o casamento do ausente, o Código português remete às leis canônicas a decisão sôbre a licitude ou não de nôvo casamento do cônjuge do ausente - art. 116, 2. É visível que, em matéria de ausência, o Código brasileiro exerceu forte influência sôbre o nôvo diploma luso. O que não exclui o fato de terem sido adotadas soluções por vêzes bem distintas das nossas.

d) Domicílio.

O conceito é dado pela expressão "lugar de residência habitual". A inspiração parece-nos ser a do Código alemão, que fala em ständig niederlassen - residir permanentemente - como forma de estabelecimento do domicílio. O conceito de dimora abituale é dado no Cód. Italiano para a residência - art. 43, al. 2 - e não para o domicílio. Evita-se assim o subjetivismo do ânimo definitivo do art. 31 brasileiro. $O$ mesmo dispositivo português que estamos analisando - art. 82, 1 - prevê o domicílio dos que residem alternadamente em vários lugares em forma extremamente semelhante à contida no nosso art. 32. O art. 83 prevê o conceito de domicílio profissional - o lugar onde a profissão é exercida - e também aí se admite, na esteira do sistema alemão, aceito também entre nós, pluralidade domiciliar. É previsto ainda o domicílio eletivo, exigida a forma escrita para a sua estipulação - art. 84 . Os arts. 85 a 88 prevêem os vários tipos de domicílio legal - o dos menores e interditos, o de mulher casada, o dos empregados públicos, o dos agentes diplomáticos portugueses. Não há novidade a assinalar.

(10) BMJ n.o 105. 


\section{e) Direitos da Personalidade.}

Tais direitos, que pela Doutrina assim vêm sendo designados, à falta de melhor denominação, estão regulados do art. 70 ao art. 81 . Protege-se a honra das pessoas já falecidas - art. 71 - regulando-se a legitimidade ativa para a ação a ser movida pelos familiares do morto. A fonte inspiradora parece ter sido o Código helênico, art. 57. Protege-se o direito ao nome - art. 72 - permitindo-se que seu titular se oponha a que outrem o use ilìcitamente para sua identificação, ou outros fins. O pseudônimo notório é protegido - art. 74 na esteira do código italiano, art. 9. São também protegidas as cartas-missivas confidenciais, que só podem ser publicadas com 0 consentimento de seu autor e, da mesma forma, as memórias familiares, e outros escritos confidenciais ou íntimos - arts. 75 a 77. Também é protegida a imagem ou o retrato das pessoas - art. 79 -, a reserva sôbre a intimidade da vida privada - art. 80 - e prevista a nulidade da limitação voluntária ao exercício dos direitos de personalidade, se contrária aos princípios de ordem pública, em dispositivo (art. 81) que, como está redigido, é evidentemente ocioso. Um dispositivo de caráter genérico - o do art. 70 - prevê ofensas atípicas à personalidade física ou moral (al. 1) e desde logo prevê as ações concedidas ao ofendido (al. 2): além da ação de responsabilidade civil, as destinadas a evitar a consumação da ameaça ou a atenuar os efeitos da ofensa já cometida. Sente-se a influência do Código helênico, art. 57, tendo sido preferida essa técnica, a de prever medidas amplas e genéricas, à técnica mais minuciosa com que o Código italiano amplamente protegeu o nome ou a imagem, mas deixou sem previsão a defesa de outros direitos de personalidade não tipificados. Bastante atualizado no particular, o Código português, no entanto, foi menos completo que o Projeto brasileiro do Prof. ORLANDO GOMES, especialmente no que toca aos problemas ligados ao corpo humano - atos de disposição do próprio corpo, do cadáver, direito a decidir sôbre o sepultamento, recusa a tratamento, a exame ou a perícia médica, arts. 29 a 34.

\section{Pessoas coletivas:}

\section{a) Terminologia.}

Ressalte-se inicialmente que a dicotomia terminológica adotada (pessoas naturais e pessoas jurídicas) pelo Código Brasileiro - e que dá uma idéia do caráter natural da personalidade do Homem, e do caráter analógico da personalidade das pessoas jurídicas, é superior à solução portuguesa. Em fim de contas, as fundações não são coletividades. 


\section{b) As sociedades na História do Direito, no Direiło Brasileiro, e no Direito Português.}

É conhecido o fato de que do Direito Romano vieram até nós dois tipos fundamentais de organizações coletivas - as associações, os antigos collegia, e as sociedades, as antigas societates. Ao lado delas, desenvolveram-se as fundações, que constituem figura à parte. Cedo, a Doutrina reconheceu que a natureza jurídica das associações correspondia de modo muito mais intuitivo à personalidade jurídica, dado a radical separação entre seu patrimônio e o dos associados, quer do ponto de vista dos créditos, quer dos débitos, quer dos bens, inclusive na eventualidade de uma liqüidação por dissolução, à qual em regra, não se segue partilha nas associações, ao contrário das sociedades, e dada também a circunstância de que a associação normalmente sobrevive aos associados, enquanto que a sociedade de tipo clássico dissolve-se com a morte do sócio. Daí derivou a tradicional ojeriza da doutrina dos países latinos - sobretudo enquanto permaneceu intocada a doutrina que inspirou o Código $\mathrm{Na}$ poleão - ao reconhecimento da personalidade jurídica das sociedadades, civis ou mercantis, em ambos os casos de finalidade lucrativa, ao contrário das associações, de fins não-lucrativos. Aos poucos, porém, o sucesso de tipos societários em que havia uma separação mais acentuada entre sócio e sociedade - especialissimamente no caso das sociedades anônimas e no das por quotas de responsabilidade limitada, principalmente do ponto de vista da responsabilidade dos sócios - ao mesmo tempo que perdia prestígio o princípio clássico de que a sociedade se dissolve com a morte do sócio, fêz com que os juristas reconhecessem, embora tímida e gradativamente, a personalidade, primeiro das sociedades comerciais, depois das civis. Essa evolução seria mais rápida em França do que na Bélgica, por exemplo, apesar da identidade de Código. ('1) Ora, o Código brasileiro, a nosso ver com acêrto, ignorou essa polêmica, concedendo a personalidade jurídica, quer a associações, quer a sociedades. Cometeu, porém, grave falta - a de não distinguir de modo suficiente os dois tipos - associações e sociedades - principalmente na obscura e deficiente redação do art. 16, I. Essa falha é corrigida pelos Projetos brasileiros, recentemente abandonados pelo Govêrno. O de Código Civil regula as associações e as fundações. O de Código das Obrigações regula as sociedades e, embora em grande parte baseado no Código italiano, possui radical dispositivo, inexistente no diploma peninsular de 1942, pelo qual é reconhecida

(11) DE PAGE, HENRI, Traité élémentaire de droit civil belge. 2. ed. Bruxelas, E. Bruylant, 1948 , t. I, p. 578. 
a persona!idade jurídica de tôdas as sociedades, desde que inscrevam, no registro próprio e na forma da lei, seus atos constitutivos art. 1.122, Ora, o Código luso distingue de modo claro sociedades, associações e fundações. O que não é claro, porém, é a personalidade jurídica das primeiras. O art. 157, que abre a parte do Código referente às "pessoas coletivas" informa que as disposições referentes às pessoas coletivas são aplicáveis às associações, às fundações, e, quando a analogia das siłuações o justifique, também às sociedades (ainda às sociedades, no texto). $O$ que fornece argumento antes a quem negue a personalidade jurídica das sociedades no Direito luso que a quem a afirme. A análise da Parte Especial não esclarece melhor. O Código luso seguiu a esteira do Italiano, dos dispositivos dêste atinentes à società semplice. Por isso, embora tenha vedado a compensação entre o débito de terceiro para com a sociedade, e o crédito do mesmo terceiro para com sócio, bem como a compensação entre o débito da sociedade para com terceiro e o crédito de sócio para com o mesmo terceiro (Port.: art. 1.000; It.: art. 2.271) deu caráter solidário à responsabilidade subsidiária dos sócios pelas dívidas da sociedade (Port.: art. 997; It.: art. 2.270). Mais clara a separação entre sócios e sociedade - e, portanto, a personalidade jurídica desta - no Direito Brasileiro. Além do princípio geral do art. 16, I, considerando pessoas jurídicas, de um modo geral, tôdas as sociedades, princípio que se completa com a referência do art. 16, II às sociedades mercantís, há o princípio firmado pelos arts. 1.396 e 1.398, que caracterizam a responsabilidade subsidiária dos sócios não como solidária, mas como proporcional à parte do sócio nas perdas sociais.

\section{c) C Código Português, as associações e as fundações.}

No que tange às associações e fundações, o Código luso permaneceu apegado ao sistema francês de aquisição da personalidade jurídica sòmente a partir do reconhecimento por ato do Govêrno, em que se individua a associação ou fundação reconhecida. Sente-se nìtidamente a presença de uma organização estatal polìticamente ciumenta, a temer a autonomia dos grupos humanos intermediários. O sistema adotado no Brasil - aquisição da personalidade e da plena capacidade pelo registro dos Estatutos - é muito mais condizente com os ideais democráticos. Só resta almejar que os sintomas que entre nós já se prenunciam de mudança de orientação, sobretudo no que toca às associações estudantis, não terminem por empanar uma das mais belas tradições jurídicas brasileiras - o apêgo ao princípio jurídico da liberdade de associação. O Código português, no caso específico das associações, demonstra um ranço da inglória 
luta pombalina contra a "mão morta": lá está um dispositivo odioso - o do art. 161, al. 2 - a vedar às associações, sob pena de nulidade, a aquisição de imóveis a título oneroso, bem como a alienação ou oneração a qualquer título, a não ser em caso de autorização governamental. Resta dizer que a estrutura das associações é minuciosamente regulada, previstos de modo obrigatório assembléia geral, administração e conselho fiscal. Também nos parece preferível a maior liberdade deixada, no Brasil, aos estatutos associativos. Não há diferenças de monta a assinalar, no caso das fundações. A exemplo do código italiano, são reguladas, como entidades não personificadas, as associações não reconhecidas e as comissões especiais.

\section{As coisas.}

Não julgamos necessários nem possíveis, nos limites dêste trabalho, maiores esclarecimentos sôbre as coisas, tal como reguladas pelo Código Civil Português, Parte Geral. As coisas imóveis são definidas por um critério de enumeração e, por exclusão, delimitadas as móveis. Fonte: art. 812 do Código Italiano. São definidas as partes integrantes como as coisas móveis ligadas materialmente ao prédio com caráter de permanência (a definição tem por fonte o § 95 do $B G B$, invertida a redação, pois o dispositivo alemão define ○ que não é parte integrante: zu den Bestandteilen eines Grundstücks gehören NICHT...) e definidas as coisas compostas, ou universalidades de fato, a partir da regra do art. 816 do Código Italiano. Ás coisas fungíveis são definidas como as que se determinam por seu gênero, qualidade e quantidade, quando constituam objeto de relações jurídicas (art. 207) definidas as consumíveis (art. 208) em definição idêntica à da primeira parte do art. 51 de nosso Código (consuntibilidade física), conceituadas coisas divisíveis (art. 209) como as que podem ser fracionadas sem alteração de sua substância, diminuição de valor ou prejuízo para o uso a que se destinam, definidas coisas acessórias ou pertenças a exemplo do Código Italiano, art. 817, e, invertido o disposto no diploma italiano, art. 818, afirmado (art. 210,2) que os negócios jurídicos que têm por objeto a coisa principal não abrangem, salvo declaração em contrário, as coisas acessórias, são definidas as coisas futuras (art. 211), divididos e classificados os frutos em fórmulas clássicas (art. 212), regulado o direito ao frutos e, finalmente, em fórmula muito semelhante à do art. 63 brasileiro, o art. 216 classifica as espécies de benfeitorias, definindo-as. O mesmo art., em sua al. 1, oferece uma definição geral de benfeitorias - "tôdas as despesas feitas para conservar ou meIhorar a coisa" - à qual teríamos reparos a fazer, do ponto de vista conceitual, já que não nos parece correta a identificação entre a 
despesa e o melhoramento a que a mesma se destina, só a êste podendo aplicar-se, a nosso ver, a designação de benfeitoria.

\section{Negócio jurídico:}

\section{a) Modalidade da declaração.}

Admite o Código português que a declaração negocial de vontade seja expressa ou tácita - a expressa abrange outros meios que não apenas a palavra e o escrito. A tácita deduz-se de fatos que, com tôda a probabilidade, a revelam. O silêncio também é admitido como veículo de declaração negocial, quando tal valor lhe seja atribuído por lei ou convenção. Êsses dois arts., 217 e 218, constituem os marcos iniciais de uma teoria geral do Negócio Jurídico, que inexiste em nosso Código, e que é desenvolvida pelo diploma luso. $\bigcirc$ nosso art. 1.079, que cuida de parte da matéria desenvolvida pelo 217 português, está nas disposições gerais sôbre contratos, fazendo falta uma doutrina geral do negócio jurídico.

\section{b) Forma.}

Consagra-se o princípio da forma livre como regra geral, sendo excepcional a forma especial, em lei determinada. O art. 219 português é extremamente semelhante ao nosso 129 e o 220, que prevê a sanção de nulidade para a preterição da forma legalmente prescrita, salvo caso de diferente sanção em lei prescrita, ao nosso 130. O art. 221 menciona, regulando assunto em que nosso Direito legislado é lacunoso, qual o valor a ser atribuído às estipulações anteriores ou posteriores ao documento para o qual exige a lei forma especial, quando tais declarações não tenham obedecido a essa forma especial. O art. 222 equaciona o mesmo problema, para o caso de forma convencional: se estipulada pelas partes uma forma especial, presume-se tal forma essencial à validade do ato, salvo quando a estipulação de forma seja concomitante ou posterior ao negócio jurídico, caso em que a presunção é de consolidação ou aperfeiçoamento do negócio jurídico, não de substituição.

\section{c) Perfeição do Negócio Jurídico.}

Exatamente por contar o Código português uma teoria geral do negócio jurídico, ao contrário do nosso, a opção que faz em tôrno das doutrinas sôbre aperfeiçoamento dos negócios jurídicos, momento do surgimento do vínculo negocial, é mais perfeita e ampla. Dividem-se as declarações de vontade em receptícias e não-receptícias. Quanto às receptícias, tem particular importância o problema dos negócios entre ausentes. Nosso Código optou pela teoria da expedição, fazendo-o porém - art. 1.086 - tão só ao cogitar da 
aceitação do oblato. É natural, pois nosso Código só cogitou dos contratos. Para o diploma português, porém, que se ocupa do assunto de modo a abranger os negócios jurídicos unilaterais, o problema tem caráter mais lato: importa saber quando se vincula o primeiro declarante, se o negócio é unilateral. O Código português opta pela teoria - alemã e suíça - da recepção. É no momento em que a declaração chega ao poder - zugeht - do destinatário que ela se torna eficaz. A teoria da cognição influi no sentido de criar uma alternativa: se o destinatário toma conhecimento da declaração, ainda que esta não haja chegado a seu poder, há eficácia vinculante. A culpa do destinatário, determinante da intempestividade da recepção da declaração equipara-se à recepção: a declaração é eficaz, art. 224, 2. Como o é também, ao contrário, a declaração recebida pelo destinatário em condições de, sem culpa sua, não poder ser conhecida. A teoria da expedição atende aos interêsses do declarante. A do conhecimento aos do destinatário. A da recepção, criando uma espécie de cognição presumida, procura conciliá-los, observa VAZ SERRA. $\left({ }^{12}\right)$ A morte ou incapacidade supervenientes do declarante não prejudicam a eficácia da declaração, a exemplo do Direito alemão, sendo ainda regulados o período de duração da eficácia da proposta, a recepção tardia (art. 299, 1 - semelhante ao brasileiro 1.082). A teoria da recepção é mantida no caso de proposta de contrato - art. 230, 1. É ainda regulada a retratação do proponente (art. 230, 2: semelhante ao brasileiro 1.081, IV), a aceitação com modificações (art. 233 semelhante ao 1.083 brasileiro), a dispensa da aceitação (art. 234, semelhante ao 1.084 brasileiro) a retratação da aceitação (art. 235, 2, semelhante ao 1.085 brasileiro) e, com idêntica solução, a retratação da rejeição, importando em aceitação - 235, 1. A culpa in contrahendo é definida a partir da noção de boa fé - art. 227.

\section{d) Interprełação e integração do negócio jurídico.}

A interpretação é feita informa RUI DE ALARCÃO, autor do respectivo Anteprojeto $\left({ }^{13}\right)$, de acôrdo com a teoria da impressão do destinatário - "o sentido que um declaratário normal, colocado na posição do real declaratário, possa deduzir do comportamento do declarante, salvo se êste não puder razoàvelmente contar com êle" - art. 236, 1. Mas caso o destinatário conheça a vontade real do declarante, esta - teoria da vontade - é que prevalecerá. Nos casos duvidosos, prevalecem - art. 237 - as regras estabelecidas pelo art. 1.371 do diploma italiano: nos negócios gratuitos, o sentido menos gravosos para o disponente; nos onerosos, o que conduzir ao

(12) BMJ n.० 103, pág. 8

(13) BMJ n. 084 , pág. 330 
maior equilíbrio das prestações. A integração dos negócios jurídicos é feita de acôrdo com a vontade presumível das partes ou os ditames da boa fé, prevalecendo êstes em caso de conflito.

\section{e) Falta e vícios da vontade.}

A simulação é definida - melhor técnica que a enumerativa de nosso Código (mantida pelo Projeto de Código das Obrigações, baseado no Anteprojeto CAIO MÁRIO, art. 60) - como divergência entre a declaração negocial e a vontade real do declarante, havendo acôrdo entre as partes, e intuito de enganar terceiros. Sua conseqüência é, ao contrário do que sucede entre nós, nulidade absoluta do negócio jurídico - art. 241 - ressalvando-se a simulação relativa, em que o negócio dissimulado é aproveitado, se não tiver havido preterição de forma essencial - art. 241, 2. Admite-se possam os simuladores argüir, um contra o outro, a nulidade derivada da simulação - art. 242. Êsse princípio, que inverte o do art. 104 brasileiro, é conseqüência lógica do caráter absoluto da nulidade por simulação no Direito Português. Porém a simulação é inoponível aos terceiros de boa fé - art. 243, inspirado no italiano 1.415, 1. À simulação é equiparada a reserva mental conhecida da outra parte - art. 244, 2. Fora dessa hipótese, é irrelevante a reserva mental. A fonte da disposição é o BGB, § 116. Às chamadas declarações não-sérias, a que falta a vontade negocial, é negado efeito, mas o declaratário que acreditou justificadamente na seriedade do declarante tem direito a indenização por perdas e danos. A disposição, que está no art. 245, inspira-se no BGB, §§ 118 e 122, com aperfeiçoamentos de redação. O Código Português prevê, na realidade, três modalidades de êrro - aquêle em que, modalidade gravíssima do chamado êrro obstáculo, o declarante não tem ao menos consciência de que faz declaração negocial: o ato é ineficaz (art. 246); o êrro essencial, definido no art. 247 através do critério subjetivo do declarante, exigido o conhecimento, real ou presumido pela outra parte, de tal essencialidade: o ato é anulável, podendo tal modalidade de êrro referir-se à pessoa do declaratário ou ao objeto do negócio; finalmente, a mera inexatidão de cálculo ou de escrita, dando lugar a simples retificação - art. 249. O êrro pode ainda ser essencial por haverem as partes, por acôrdo, determinado a essencialidade do motivo sôbre o qual haja recaído o êrro. (art. 252, 1) Ao ârro sôbre a base do negócio aplicam-se as normas inspiradas na teoria da imprevisão, de que nos ocuparemos no trabalho sôbre as Fontes das Obrigações no nôvo diploma luso. O êrro essencial pode ser resultante de transmissão - art. 250 - a exemplo do art. 1.432 italiano 
e do 89 brasileiro. A noção de conhecimento real ou presumido pela outra parte da essencialidade, para o declarante, do elemento sôbre que incidiu o êrro, representa uma inovação do Código português - art. 247 - e é uma tentativa de solução do mais árduo problema em matéria de êrro - a conciliação entre o direito de uma das partes a que não tenha validade uma declaração que não guarda correspondência com sua vontade real, e o princípio de que a boa fé da outra parte não pode ser prejudicada. A solução é sensivelmente semelhante à do Código italiano - art. 1.431 - possibilidade de identificação, de reconhecimento do êrro por pessoa de normal diligência. Aqui porém (no Código de Portugal) o conhecimento, real ou presumido, através do critério abstrato da pessoa de diligência normal, não é do êrro em si mesmo, mas da essencialidade do elemento sôbre que incida. De qualquer forma, não é a culpa do declarante o critério que importará, como na chamada teoria da responsabilidade. O dolo é definido no art. 253,1. O art. 253,2 inclui na categoria do chamado dolus bonus, irrelevante, o dolo por omissão quando "nenhum dever de elucidar o declarante resulte da lei, da estipulação negocial ou das concepções dominantes no comércio jurídico. O ato jurídico em que tenha havido dolo é anulável - art. 254. A anulabilidade não se exclui pelo fato de ser bilateral o dolo, ao contrário do disposto no Código Brasileiro, art. 97. Não contém o Código luso qualquer alusão ao dolo acidental, que o nosso Código define no art. 93 como aquêle a despeito do qual "o ato se teria praticado, embora por outro modo" e que, não afetando embora a validade do ato, dá direito a perdas e danos. É superior a solução brasileira que, sem se contentar com os princípios gerais da responsabilidade civil, explicitou figura à parte de dolo, que não se compadece com a distinção entre bonus e malus (própria apenas do dolo essencial) e que consagra, na prática, o direito a pleitear a diferença entre a vantagem obtida pelo ato jurídico e aquela que se obteria se 0 ato jurídico tivesse sido praticado de modo diferente, sem o dolo acidental. A norma brasileira consagra a chamada Differenzklage do Direito alemão. A coação moral - vis compulsiva - também torna anulável o ato ịurídico - arts. 255 e 256 . A vis absoluta torna-o nulo por falta de vontade, que da vontade viciada se distingue - art. 246. Preferível a precisão do Código luso à omissão do diploma brasileiro nesse ponto. Mais correto porém teria sido considerar o ato em tal caso inexistente por falta de vontade.

\section{f) Representação.}

A representação é regulada, com normas gerais e com normas peculiares à representação voluntária. Na parte especial do diploma, 
são regulados o mandato com e o mandato sem representação. Predomina a teoria da representação, de WINDSCHEID, que influiu no BGB e no Código italiano de 1942: os vícios de vontade que tornam o ato nulo ou anulável hão de ser os do representante, não os do representado. Duas ressalvas, porém, se introduzem - o caso dos elementos em que tenha sido decisiva a vontade do representado, e a boa fé do representante (que não aproveita ao representado de má fé). A fórmula do art. 259 do Código lusitano foi nitidamente inspirada pelos arts. 1.390 e 1.391 do Código Italiano.

\section{g) Condição e têrmo.}

São definidos de modo clássico. Ao contrário do Código Brasileiro, em que a condição fìsicamente impossível tem-se por inexisitente enquanto a juridicamente impossível invalida os atos a ela subordinados (art. 116), o Código português adota a solução de declarar nulo o negócio jurídico subordinado a condição ilícita ou imoral ou impossível, física ou legalmente; quanto à impossibilidade, porém, tal solução restringe-se à condição suspensiva. Se resolutiva a condição, será considerada, se impossível, não escrita. A solução adotada é exatamente a do Código italiano, art. 1.354, e do projeto brasileiro de Código das Obrigações, art. 28, e seu $\S 1 .^{\circ}$. Filiando-se ao sistema franco-italiano, o Código português estabelece a regra geral da retroatividade dos efeitos da verificação da condição. O Brasil adotou o sistema oposto, alemão, omitindo tal regra, no Código e no Projeto.

\section{h) Negócio jurídico nulo por ilicitude ou impossibilidade.}

Sob o título "Objeto negocial. Negócios Usurários" - o Código português ocupa-se em verdade de dois assuntos: a nulidade por ilicitude ou impossibilidade do objeto e o velho instituto da lesão. Quanto ao $1 .^{\circ}$ assunto, 0 art. 280 consagra a nulidade por impossibilidade física ou legal, por indeterminabilidade do objeto, por ilicitude - em face da ordem pública e dos bons costumes. Introduz, porém, ○ art. 281 uma distinção: se apenas o fim visado fôr contrário à lei, ordem pública ou bons costumes, só ocorrerá a nulidade no caso de ser o fim comum a ambas as partes. De certa forma, é a introdução no sistema luso da doutrina francesa sôbre causa, já que esta tradicionalmente é entendida (se usarmos a terminologia aristotélica) no sentido de causa final. Trata-se de novidade no Direito Português, que parece aderir agora à corrente causalista. A fórmula adotada reflete a influência do Código Italiano de 1942, 
feita a fusão entre os artigos 1.343 e 1.345 dêste, aparentemente recusada a distinção entre causa (no sentido de fim típico), e motivos (no sentido de fins especificamente visados pelas partes, no caso concreto). A noção de motivo só aparece, como vimos, em matéria de êrro - art. 252.

\section{i) Lesão.}

1. As três vertentes no Direito Comparado. Na realidade, três grandes vertentes existem, no Direito Contemporâneo, em matéria de lesão.

A) a vertente francesa. O Código Napoleão não ofereceu uma noção geral de lesão. Embora o art. 118 classifique a lesão dentre os vícios do consentimento, tal dispositivo deixa clara a inexistência de uma norma geral de lesão, pois esta ne vicie les conventions que dans certains contrats ou à l'égard de certaines personnes. Deixado de lado o caso dos menores, em que na realidade o problema é de restitutio in integrum, é na compra e venda que o Código francês colocou o campo por excelência da lesão. Apesar de considerada vício do consentimento pelos autôres do Código, parece-nos, em que pesem respeitáveis opiniões em contrário, que essa classificação não deslocou para o âmbito do subjetivo a lesão no Direito frar:cês. A classificação tem importância no sentido de que deixa claro ser a ação de rescisãa por lesão concedida em atenção ao prejuízo sofrido por quem emitiu seu consentimento de forma viciada. Mas êsse vício é apurado de forma objetiva, presume-se a partir da desproporção entre as prestações, que o Código Napoleão, a exemplo dos textos romanos, tarifa. Só que o tarifamento é alterado de metade (Dto. Romano) para 7/12 - si le vendeur a été lésé en plus de sept douzièmes dans le prix d'un immeuble... - art. 1.674 do Código Civil Francês. A ação é concedida apenas ao vendedor do imóvel e é de rescisão do negócio. Também por ser classificada como vício do consentimento, o valor é estimado de acôrdo com o momento da venda. Ao comprador cabe a opção (art. 1.681) entre a devo!ução da coisa com retomada do preço e o oferecimento da diferença entre o preço pago e o preço justo. O Code Civil estendeu o instituto à partilha na sucessão hereditária, em favor de qualquer dos co-herdeiros. Aqui, o tarifamento é simplesmente de $1 / 4$ do valor do bem ou bens partilhado(s). A estrutura é porém a mesma - ação de rescisão, podendo o réu impedir a rescisão com o oferecimento da diferença de valor.

B) a vertente alemã. $O$ famoso $\S 138$ do BGB deslocou completamente o problema. Boa parte da doutrina entende que, no Di- 
reito alemão, o que ressurge é a usura real dos canonistas medievais, e não mais a lesão. Vejamos o texto do $\S 138$ - Eins Rechłsgeschäft, das gegen die guten Sitten verstösst, ist nichtig. Ou seja - "E nulo um negócio jurídico contrário aos bons costumes". E agora a alínea 2. ${ }^{a}$ do $\S$, fundamental no caso - Nichtig ist insbesondere eins Rechtsgeschäft, durch das jemand unter Ausbeutung der Notlage, des Leichtsinns oder der Unerfahrenheit eines anderen sich oder einem Dritłen für eine Leistung Vermögensvorteile versprechen oder gewärhren lässt, welche den Wert der Leistung dergestalt übersteigen, dass den Umständen nach die Vermögensvorteile in auffäligen Missverhälinnisse zu der Leistung stehen. Ou, em tradução tão literal quanto possível - "É nulo em especial um negócio jurídico através do qual alguém, com exploração da necessidade, da leviandade ou da inexperiência de outrem, consegue que esta outra pessoa prometa ou conceda, em favor do agente ou de terceiro, vantagens patrimoniais que ultrapassem de tal modo o valor da contra-prestação que, levadas em conta as circunstâncias, estejam com esta em chocante desproporção". É evidente o caráter múltiplo das alterações introduzidas no velho instituto. Introduz-se a chamada qualificação da lesão - o chamado dolo de aproveitamento - exploração da necessidade, da leviandade, ou inexperiência da outra parte. É judicial o critério da desproporção, para aferir a qual não oferece a lei tarifamento, mas mero padrão geral - vantagens patrimoniais em chocante desproporção (in auffäligen Missverhältnisse), levadas em conta as circunstâncias, com o valor da contra-prestação (Leistung). A sanção é a nulidade absoluta do negócio jurídico, considerado em tal caso (al. $1 .^{a}$ ) como contrário aos bons costumes. O que justifica a observação de ORLANDO $\left({ }^{14}\right)$ - enquanto, no sistema francês, protege-se o lesado, que não teria consentido se conhecesse $\circ$ prejuízo, a lesão sofrida ao contratar, e que, por isso mesmo, rescindirá - negócio se o quiser, no sistema alemão "leva-se em conta sobretudo o estado de espírito do explorador". E como êsse estado de espírito é contrário aos bons costumes e, de outra parte, conduziu a negócio jurídico em si mesmo contrário aos bons costumes, a sanção é a nulidade absoluta. Dentre outros, seguiu o modêlo alemão o Código helênico, arts. 179 e 180.

C) a vertente italiana. Procurando conciliar as duas fórmulas, dispõe o art. 1.448 do Código Italiano, sob o título Azione generale di rescissione per lesione que, se vi è sproporzione tra la prestazione di una parte e quella dell'altra, e la sproporzione è dipesa dallo stato

(14) ORLANDO GOMES, "Transformações Gerais do Direito das Obrigações", ed. Revista dos Tribunais, S. Paulo, 1967, especialmente página 33. 
di bisogno di una parte, del quale l'altra ha approfittato per trarne vantaggio, la parte danneggiata può domandare la rescissione del contratto. Combinam-se assim os dois requisitos exigidos pelo diploma alemão: o requisito objetivo da desproporção e o requisito subjetivo do dolo de aproveitamento, resumido agora na fórmula "tirar proveito do estado de necessidade da outra parte". A exemplo do BGB, fornece-se uma fórmula genérica, que abrange, na Itália, os contratos comutativos, em geral. Mas, a exemplo do sistema francês, a desproporção é tarifada - la azione non è ammissibile se la lesione non eccede la metà del valore che la prestazione eseguita 0 promessa dalla parte danneggiata aveva al tempo del contratto. E o que é mais, a sanção não é de nulidade, como na Alemanha, mas de rescisão, como na França, podendo o réu da ação de rescisão art. 1.450 - oferecer una modificazione del contratto sufficiente per ricondurlo ad equità, evitando com isso a rescisão. Sente-se a hesitação entre a fórmula germânico-medieval, de usura real, em que é o interêsse público de mantença dos bons costumes que prepondera e, ferido, nulifica o negócio jurídico, e a fórmula romano-francesa, em que a atenção é dirigida ao interêsse privado lesado, admitidas por isso mesmo possíveis composições, possíveis exatamente porque a matéria não é tratada pelo ângulo do interêsse público.

II. O Direito Brasileiro. Nosso Código Civil, fiel à orientação de CLOVIS, desprezou o velho instituto, que as Ordenações contemplavam. O Anteprojeto de Código das Obrigações de 1941, da autoria de OROZIMBO NONATO, PHILADELPHO AZEVEDO e HAHNEMANN GUIMARÃES, sofreu nítida influência do sistema alemão. Contempla como elementos conceituais do instituto a circunstância de haver a declaração de vontade sido emitida em função da premente necessidade ou inexperiência, dela resultando, para seu autor, obrigação a "prestação manifestamente desproporcionada ao proveito resultante da prestação oposta". É evidente a preocupação de investigação e censura da conduta do beneficiado pelo ato, pois é exigido, para caracterizar-se a lesão, que tenha ocorrido "abuso praticado em situação de desigualdade volitiva para contratar" (art. 31). Considerada, porém, a lesão, como defeito da vontade, a sanção é a anulabilidade do negócio jurídico. Em monografia já hoje clássica, CAIO MÁRIO DA SILVA PEREIRA $\left({ }^{15}\right)$ buscou demonstrar a existência do instituto no Direito vigente, localizando-o principalmente na norma penal que pune a usura real. É que por serem contratos com objeto ilícito os que envolvam o crime de usura real, a sanção é de nulidade, com

(15) CAIO MÁRIO DA SILVA PEREIRA, "Lesão nos Contratos", Forense, Rio 1959, sendo de 1949 a $1 .^{a}$ edição. 
base no art. 145, II do Código Civil. Porém o Projeto de Código de Obrigações que resultou do Anteprojeto do civilista mineiro preferiu filiar-se ao sistema italiano. O Projeto consagra em seu art. 64 uma definição de lesão a partir da vantagem desproporcional, ou exageradamente exorbitante da normalidade, associando êsse requisito objetivo ao subjetivo - abuso da inexperiência ou premente necessidade da outra parte. A sanção é a ação de rescisão (art. 77) e a parte favorecida poderá, para evitar a rescisão - art. 79 - oferecer suplemento suficiente ou concordar com a redução do proveito. Além disso, a lesão é classificada dentre os "defeitos dos negócios". ORLANDO GOMES, no trabalho citado, teve ocasião de sustentar a imprestabilidade de uma técnica meramente privatística de rescisão para a defesa dos humiliores contra os potentiores, eis que esta é a finalidade contemporânea do instituto. Embora não subscrevamos a evidente preferência do mestre baiano pelas sanções penais (pois considera, no fundo, caducas e inúteis ambas as fórmulas modernas da lesão) concordamos em que o caráter híbrido da fórmula italiana é pouco feliz e de difícil exeqüibilidade como defesa eficaz dos econômicamente mais fracos. Confessamos nossa preferência pelo sistema germânico de nulidade absoluta.

III. O Código Português. Embora fale em negócios usurários, o diploma lusitano fica, no fundo, com a fórmula italiana. Só a conceituação das bases do instituto é germânica. Ocorre usura quando (art. 282) "alguém, aproveitando conscientemente a situação de necessidade, inexperiência, dependência ou deficiência psíquica de outrem, obteve dêste, para si ou para terceiro, a promessa ou concessão de benefícios manifestamente excessivos ou injustificados". A desproporção - como, aliás, no Projeto brasileiro - não é tarifada. Mas a consequiência é a anulabilidade do negócio jurídico, admitida sua modificação "segundo juízos de eqüidade", como ersatz da anulação, quer a requerimento do Autor, quer a pedido do Réu. Paradoxalmente, vincula-se a prescrição da ação - art. 284 - à da ação penal por eventual crime de usura e, como a marcar a influência medieval, assegura-se ao mútuo tratamento próprio, semelhante ao da lei brasileira de usura, exatamente porque o mútuo é o campo da usura pecuniária, e a usura real tem por campo outros negócios jurídicos. Adotado pelo Código luso o modêlo italiano, consideramos que lhe é aplicável a irrespondível e lapidar crítica que ao sistema peninsular dirige ORLANDO GOMES (16): "De duas, uma: ou é atentatória dos bons costumes a conduta de quem tira proveito desproporcional explorando a necessidade ou a inexperiência de outrem e,

(16) ORLANDO GOMES, "Transformações", op. cit., págs. 37, 41, 44 e 43. 
nesse caso, o contrato deve ser fulminado com a sanção de nulidade, ou não se pode exigir o requisito da exploração para qualificar pretensa lesão. (...) O arrependimento forçado, admitido em lei, é a consagração mutatis mutandis da tese de que sòmente há furto se o ladrão é descoberto. (...) Pode muito o legislador, mas não the é dado legitimar absurdos lógicos. Por mais que possa, não pode proibir e permitir ao mesmo tempo". Até aí, a crítica no campo lógico e técnico. A crítica prossegue, porém, já agora no campo da eficácia social. "A fidelidade dessas legislações à tese individual retira-lhes, ademais, a significação prática que poderia ter a transformação em direito positivo de um princípio de justiça contratual. O clima próprio aos atentados a êsse princípio é, hoje, o que favorece a conclusão dos chamados contratos estrangulatórios e os que repercutem na economia popular. Não faz sentido, em relação a êsses negócios jurídicos, a ação individual para rescindí-los. (...) o conceito conserva resíduos individualistas que o desacreditam perante os pressupostos éticos do Direito atual, prêso que se acha à tentativa de conciliar o princípio da autonomia da vontade com o da justiça comutativa, e dando àquele predominância sôbre êste ao exigir que o prejudicado prove ter sido vítima da exploração de sua necessidade ou inexperiência." É pretender "destruir uma fortaleza com um tiro de bacamarte".

\section{¡) Insubsistência do negócio jurídico.}

I. Inexistência e ineficácia. Não cogitou o Código português, em capítulo especial a isso dedicado, da inexistência dos negócios jurídicos. O autor do Anteprojeto, RUI DE ALARCÃO, reconhecendo embora a validade doutrinária da figura da inexistência, preferiu deixá-la sem regulação legal, deixando o problema para a doutrina, "atentas as graves dúvidas e divergências que o problema suscita e ser relativamente escasso o seu interêsse prático". (17) Discordamos do autor luso. Oriunda do Direito Matrimonial, a noção de negóciojurídico inexistente tem inúmeras aplicações importantes no campo dos negócios jurídicos em geral, como o caso em que não tenha havido consentimento (p. ex. por ter uma pessoa falsificado a assinatura de outra, por quem se fêz passar) o caso em que uma das partes não exista, trate-se de uma pessoa fictícia criada para fins criminosos. Há aí muito mais que um ato viciado por simulação. Há um não-ato, um não-ser, um nada, ontològica e jurìdicamente. Quanto ao problema do interêsse prático, desejaríamos lembrar apeum aspecto - no caso dos atos nulos, o brocardo quod nullum est,

(17) BMJ n.० 89, pág. 201. 
nullum effectum... sofre exceções, havendo casos de efeitos jurídicos de atos nulos. Quanto aos atos inexistentes, sua ineficácia jurídica é total, radical, sem exceções. O exemplo clássico é o dos filhos, legítimos no caso do casamento nulo putativo, enquanto a putatividade é conceito inaplicável ao casamento inexistente. Mas, para ficarmos no campo da teoria geral do negócio jurídico, gostaríamos de dar um exemplo tirado do próprio Código português. Êste, em seu art. 289,3 manda aplicar, quer aos atos nulos, quer aos anuláveis, as regras dos artigos 1.269 e seguintes, que regulam o problema da boa ou má fé na posse e suas conseqüências em matéria de responsabilidade por perda ou deterioração da coisa, direito aos frutos, direito de indenização por benfeitorias, direito de levantamento, encargos, deteriorações. A posse em virtude de um contrato nulo pode ter sido de boa-fé, e daí decorrerão determinadas conseqüências. Parece-nos inaplicável o princípio ao contrato inexistente em virtude do qual tenha havido posse. E isso sem falar no problema dos prazos prescricionais. Nesse terreno, tem sido fecunda no Direito Brasileiro a distinção entre nulidade e inexistência.

Quanto à ineficácia em sentido estrito, também não aparece no capítulo específico, destinado às causas de insubsistência do negócio jurídico, estando a matéria esparsa pelo Código, nos vários casos em que surge.

II. Nulidade e anulabilidade: causas. No que tange à nulidade ou à anulabilidade, fazem falta alguns dispositivos, no capítulo de que ora nos ocupamos, que compendiassem, à maneira de nossos 145 e 147, as várias causas de nulidade e anulabilidade. Do exame feito na Parte Geral do Código Português, extraímos uma enumeração que não tem, evidentemente, pretensões à taxatividade.

São, no Código Português, causas de nulidade:

1) a impossibilidade, física ou legal, a indeterminabilidade ou a ilicitude do objeto do negócio jurídico; a ilicitude e imoralidade do próprio negócio jurídico (art. 280);

2) a circunstância de, em determinado negócio jurídico, ser o fim, comum a ambas as partes, ilícito, ilegal ou imoral (art. 281);

3) o caráter ilegal, ilícito (contrário à ordem pública) ou imoral (contrário aos bons costumes) da condição a que o negócio se subordine; e o caráter de impossibilidade, física ou legal, de que se revista a condição suspensiva a que o negócio se subordine (art. 271); 
4) a celebração do negócio jurídico com desobediência à forma prescrita em lei, quando não seja outra a sanção para a preterição da forma (art. 220);

5) a simulação (art. 240,2);

6) a reserva mental com que uma das partes, com conhecimento da outra, emitiu sua declaração (art. 244,2).

A falta de consciência na declaração e a coação física não são causas de nulidade, mas de ineficácia em sentido estrito (art. 246).

São causas de anulabilidade:

1) a incapacidade do agente, que não tenha sido representado na forma da lei, quando esta o exigisse, ou assistido, se essa assistência se impunha (arts. 125, 139, 156);

2) a prática de atos jurídicos pelo emancipado beneficiado com emancipação restrita, quando tais atos não se incluam dentre os abrangidos pela emancipação, e o emancipado não tenha sido representado (art. 136);

3) a prática do ato em estado notório de incapacidade acidental (art. 257);

4) o caráter de contrariedade à lei ou aos Estatutos de que se revistam deliberações associativas (art. 176);

5) $\circ$ êrro essencial, o dolo ilícito e a coação moral (arts. 247, 250, $252,254,256)$;

6) ○ caráter de "negócio consigo mesmo" de que se revista o ato (art. 261);

7) o caráter lesionário do negócio ("negócios usurários") (art. 282).

III - Nulidade e anulabilidade - conseqüências. É ao tratamento das consequiências da nulidade e da anulabilidade que se limita a secção que ora estudamos. $O$ art. 285 começa por deixar claro que as disposições dos artigos subseqüentes são aplicáveis à nulidade e à anulabilidade do negócio jurídico na falta de regime especial, o que deixa implícita a existência possível de nulidade e anulabilidade com regime diverso, criado eventualmente por leis extravagantes. A nulidade pode ser invocada por qualquer interessado (art. 286), enquanto a anulabilidade só 0 pode pelas pessoas em cujo interêsse a lei a tenha estabelecido (art. 287,1). São nesse ponto evidentes os precedentes italiano $(1.421$ e 1.441) e brasileiro (146 e 152). O negócio anulável é confirmável e a confirmação sana o vício - 
art. 288. A eventual confirmação é feita sem ressalva de eventuais direitos de terceiros. A ressalva dêstes, inspirada no Código francês, art. 1.338, III, já era tradicional, e nosso Código a consagra, no art. 148. O Código italiano rompeu com a tradição, no art. 1.444. Na sua esteira, o Projeto brasileiro de Código de Obrigações, art. 74, e o Código Português, art. 288, 4, êste último negando de modo explícito a ressalva - "mesmo em relação a terceiro". O art. 289 do Código Português consagra a restituição das partes ao status quo ante (Bras., 158). Na esteira dos códigos italiano e alemão, consagra o diploma português a inoponibilidade da nulidade ou anulação aos terceiros de boa fé, protegendo-se a aparência - art. 291. O problema da nulidade ou anulação parcial (art. 292) é resolvido de modo análogo à solução brasileira do art. 153. Porém apenas análogo, pois o Código Brasileiro fala em separabilidade da parte válida do ato. O Código português estabelece uma presunção de validade, admitida a prova contrária de que, sem a parte viciada, o negócio não teria sido celebrado. Derrubada a presunção, a nulidade ou anulação serão totais. No fundo, é a mesma norma do § 139 do BGB, com a inversão porém da presunção que, no código germânico, é de nulidade, e com a inversão do ônus da prova que, no diploma alemão, é da parte que deseja salvar o ato. O art. 293 permite a conversão de negócio jurídico nulo ou anulado em negócio de tipo ou conteúdo diferente, do qual contenha os requisitos essenciais de substância e forma, quando o fim perseguido pelas partes permita supôr que elas o teriam querido, se tivessem previsto a invalidade. A fonte é o $§ 140$ do BGB, com a introdução do conceito de "fim perseguido pelas partes".

\section{Prescrição e caducidade.}

Não nos permitirão os limites dêste trabalho um estudo exaustivo da matéria no Código português. Limitar-nos-emos a dizer algumas palavras acêrca do critério de distinção entre prescrição e caducidade (ou decadência) que o código português tentou. $O$ autor do respectivo Anteprojeto, Professor ADRIANO VAZ SERRA, encontrava-se diante de problema ainda mais árduo que o enfrentado pelo projetista brasileiro de Código de Obrigações, Professor CAIO MÁRIO DA SILVA PEREIRA. A doutrina portuguesa não tinha, desarmada pelo Código (nosso Código é omisso a respeito) critério uniforme para distinção. Famoso assento do Supremo Tribunal de Justiça resolveu a favor do caráter prescricional de todos os prazos de propositura de ações. Mas o advento do Código de Processo Civil deixou tal assento sem valor. Havia mesmo quem dissesse que pres- 
cricional era o prazo da extinção de direitos; decadencial o da propositura de ações. Admitida pacificamente no Código a distinção entre os dois institutos no plano das conseqüências, sente-se, porém, mesmo nesse plano, que as fronteiras entre os dois institutos são menos nítidas em Portugal que no Brasil. São critérios distintivos entre os dois institutos, no plano das conseqüências, no Código luso: interrompibilidade e suspensibilidade dos prazos prescricionais, ao contrário dos caducificantes; apreciabilidade ex-officio da caducidade, ao contrário da prescrição, que depende de invocação (artigos 318 a 322, 323 a 325, 328, 303 a 333,1). São admitidas exceções a êsses critérios, como por exemplo as derivadas de lei especial que admita interrupção ou suspensão de prazo caducificante - art. 328 , ou a que exige invocação do prazo de caducidade em matéria não excluída da disponibilidade das partes: o tècnicamente ruim art. 333,2. Por outro lado, a lei portuguesa admite renúncia ao prazo de caducidade - art. 330,1 - assim como ao prescricional 302 - ao contrário de nossa Doutrina, uniforme no considerar irrenunciável o prazo decadencial.

Restava o plano conceitual. Optou VAZ SERRA, e com êle o Código - art. 298,2 - pelo critério italiano: caducificante o prazo quando o direito deva ser exercido dentro em certo prazo. Critério que veio a ser também o adotado pelo projeto brasileiro de Código de Obrigações, art. 271. O dispositivo português acrescenta uma ressalva - "a menos que a lei se refira expressamente à prescrição". Não julgamos feliz a solução, e continuamos a preferir o critério defendido entre nós por CÂMARA LEAL, o qual nos parece preferível do ponto de vista da segurança prática e até do ponto de vista científico, em face da moderna doutrina do direito de ação. $\left({ }^{18}\right)$

As regras referentes à caducidade aplicam-se também "na falta de disposição em contrário" aos casos de extinção pelo não-uso que o Código distingue de prescrição - de direitos reais: propriedade, usufruto, uso e habitação, enfiteuse, superfície e servidões (art. 298,3). Não se confunde igualmente com a usucapião essa perda pelo não-uso, instituto que nosso Direito conhece (ex., em matéria de servidões, a perda pelo não-uso, no nosso art. 710, III, distinta da usucapião prevista pelo art. 698) mas ao qual o Código português dá tratamento mais extenso e amplo.

(18) ANTÔNIO LUÍS DA CÂMARA LEAL, "Da Prescrição e da Decadência", Forense, Rio, 2.a ed., 1959, especialmente $n .079$, págs. 123 e 124. 